\title{
The prevalence of ixodid ticks on buffaloes from eastern region of Lucknow, Uttar Pradesh
}

\author{
POONAM SINGH AND SUMAN MISHRA
}

\begin{abstract}
The present study was conducted to investigate the occurrence of ticks on buffalo. The survey was carried out between February 2016 to May 2016 at eastern region of Lucknow, Uttar Pradesh, India. The following genera of ticks belonging to the family ixodidae were recovered from buffaloes, Hylomma and Rhipicephalus (formerly Boophilus). A total of 300 buffaloes were examined out of which 160 were found infested with ticks. The overall prevalence of tick infestation in buffaloes was observed 53.33 per cent. Gender-wise prevalence of ticks showed that infestation was more prevalent in females $(56.5 \%)$ as compared to male hosts $(42.8 \%)$. Age-wise prevalence of ticks was also studied and it was observed that the

Author for Corresponding -

SUMAN MISHRA highest prevalence of ticks was in adult (>3yrs) $(23.7 \%)$ and lowest prevalence $(45.7 \%)$ was recorded in young buffaloes (1-3yrs).
\end{abstract}

Department of Applied Animal Sciences, BabaSaheb Bhimrao Ambedkar University, LUCKNOW (U.P.) INDIA

Email: drsumanmishra@gmail.com

See end of the article for

Coopted authors'
KEY WORDS....... Prevalence, Age, Sex, Buffaloes, Ticks

HOW TO CITE THIS ARTICLE - Singh, Poonam and Mishra, Suman (2017). The prevalence of ixodid ticks on buffaloes from eastern region of Lucknow, Uttar Pradesh. Asian J. Animal Sci., 12(1): 38-42. DOI : 10.15740/HAS/TAJAS/12.1/38-42.

ARTICLE CHRONICLE - Received : 11.03.2017; Revised : 08.05.2017; Accepted : 21.05.2017 